\title{
Der $\mathbf{p} 1$ facilitates transepithelial allergen delivery by disruption of tight junctions
}

\author{
Hong Wan, ${ }^{1}$ Helen L. Winton, ${ }^{1}$ Christian Soeller, ${ }^{1}$ Euan R. Tovey, ${ }^{2}$ Dieter C. Gruenert, ${ }^{3}$ \\ Philip J. Thompson, ${ }^{4}$ Geoffrey A. Stewart,${ }^{5}$ Graham W. Taylor, ${ }^{6}$ David R. Garrod, ${ }^{7}$ \\ Mark B. Cannell, ${ }^{1}$ and Clive Robinson ${ }^{1}$
}

\author{
${ }^{1}$ Department of Pharmacology and Clinical Pharmacology, St. George's Hospital Medical School, \\ London SW17 0RE, United Kingdom \\ ${ }^{2}$ Institute for Respiratory Medicine, Department of Medicine, University of Sydney, Sydney NSW 2006, Australia \\ ${ }^{3}$ Gene Therapy Core Center, Cardiovascular Research Institute, Department of Laboratory Medicine, \\ University of California-San Francisco, San Francisco, California 94143-0911, USA \\ ${ }^{4}$ Department of Medicine, and \\ ${ }^{5}$ Department of Microbiology, University of Western Australia, Queen Elizabeth II Medical Centre, Nedlands 6907, Australia \\ ${ }^{6}$ Section on Clinical Pharmacology, Imperial College School of Medicine, Hammersmith Campus, \\ London W12 0NN, United Kingdom \\ ${ }^{7}$ School of Biological Sciences, University of Manchester, Oxford Road M13 9PT, United Kingdom
}

Address correspondence to: Clive Robinson, Department of Pharmacology and Clinical Pharmacology, St. George's Hospital Medical School, Cranmer Terrace, London SW17 0RE, United Kingdom. Phone: 44-181-725-5620;

Fax: 44-181-725-3581; E-mail: c.robinson@sghms.ac.uk.

Received for publication November 18, 1998, and accepted in revised form June 1, 1999.

\begin{abstract}
House dust mite (HDM) allergens are important factors in the increasing prevalence of asthma. The lung epithelium forms a barrier that allergens must cross before they can cause sensitization. However, the mechanisms involved are unknown. Here we show that the cysteine proteinase allergen Der p 1 from fecal pellets of the HDM Dermatophagoides pteronyssinus causes disruption of intercellular tight junctions (TJs), which are the principal components of the epithelial paracellular permeability barrier. In confluent airway epithelial cells, Der $\mathrm{p} 1$ led to cleavage of the TJ adhesion protein occludin. Cleavage was attenuated by antipain, but not by inhibitors of serine, aspartic, or matrix metalloproteinases. Putative Der p 1 cleavage sites were found in peptides from an extracellular domain of occludin and in the TJ adhesion protein claudin-1. TJ breakdown nonspecifically increased epithelial permeability, allowing Der $\mathrm{p} 1$ to cross the epithelial barrier. Thus, transepithelial movement of Der $\mathrm{p} 1$ to dendritic antigen-presenting cells via the paracellular pathway may be promoted by the allergen's own proteolytic activity. These results suggest that opening of TJs by environmental proteinases may be the initial step in the development of asthma to a variety of allergens.
\end{abstract}

J. Clin Invest. 104:123-133 (1999).

\section{Introduction}

Sensitization to allergens such as house dust mite fecal pellet (HDMFP) proteins is a primary risk factor for the development of allergic sensitization and asthma (1-7). Whereas the events that occur in established asthma are understood in increasing detail, the process of allergen delivery that initiates the disease is unresolved.

When inhaled, HDMFPs contact the airway epithelium; they become hydrated and discharge their allergenic contents onto a mucosal barrier that is developmentally specialized to prevent the ingress of foreign proteins. To interact with dendritic antigen-presenting cells, potential allergens must cross the lung epithelium $(6,8)$. How allergens cross the airway lining is, therefore, central to the development of asthma, but the mechanism is unknown.

Paracellular channels, normally sealed by tight junctions (TJs) (9-11), offer a potential route for antigen penetration. TJs are macromolecular assemblies of proteins that form contiguous rings at the apices of epithe- lial cells (11). The TJ proteins ZO-1, ZO-2, ZO-3, AF-7, symplekin, $7 \mathrm{H} 6$, and cingulin $(9,12,13)$ are cytoplasmically localized. However, occludin and claudins are transmembrane proteins (14-18) involved in TJ adhesion and sealing $(19,20)$. Exogenous perturbants might disrupt this seal, increasing epithelial permeability. If allergens promoted such disruption, it might explain how they encounter antigen-presenting cells.

The group-1 HDM allergen Der $p 1$ is related to papain and could act enzymatically when inhaled (6, 21). If so, it might either disrupt the airway epithelial barrier by direct activity against TJs or, indirectly, through nonjunctional integral membrane proteins that activate TJ-regulating transduction pathways.

To investigate this fundamental step in allergic sensitization, we examined the effects of solubilized HDMFP and Der p 1 on intercellular junctions and epithelial barrier function, using Madin-Darby canine kidney (MDCK) and 16HBE140- human bronchial epithelial cell lines, 2 well-defined paradigms for inter- 


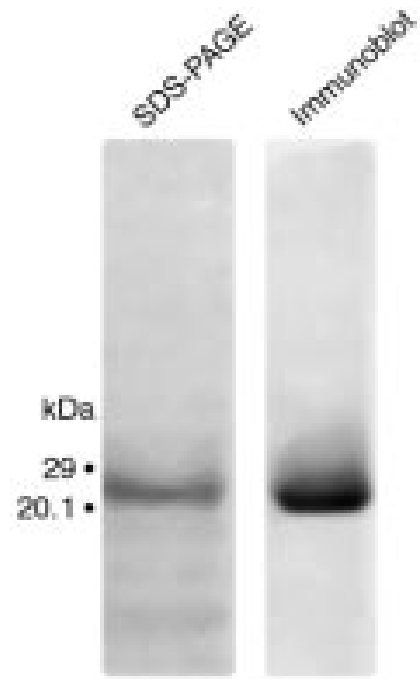

Figure 1

SDS-PAGE and immunoblot analysis of pure Der $p 1$. The electrophoresis gel was stained with Coomassie blue. Immunoblot detection was by $\mathrm{ECL}$ using $\mathrm{mAb} 5 \mathrm{H} 8$. Markers indicate the mobility of standards. Der $p 1$ migrated with an apparent mass of $\sim 24 \mathrm{kDa}$.

cellular junctional studies $(22,23)$. Experiments were conducted using numbers of fecal pellets or amounts of enzyme activity that attempted to model the exposure of human airways to these agents.

\section{Methods}

Preparation of HDMFPs and pure Derp 1. Dermatophagoides pteronyssinus were cultured in liver powder, and their fecal pellets (diameter $10-40 \mu \mathrm{m}$ ) were separated by sieving. To mimic the behavior of pellets in the domestic environment, they were "aged" for 8 months at room temperature and humidity. Pellets were solubilized in MEM with Earle's salts (EMEM) and applied to cell monolayers (24). The depth of solution over the cells was $\sim 150 \mu \mathrm{m}$, compared with the $\sim 5-10 \mu \mathrm{m}$ of fluid that normally covers the lung epithelium (25). The number of pellets was chosen as follows. Given the dimensions of the bronchial tree of adults (26) and the fact that HDMFPs are unlikely to penetrate beyond third-generation bronchi, the area exposed would be $143 \mathrm{~cm}^{2}$. Because an individual inhales $>200$ pellets per day (7) and the area of our cell monolayer was $1.3 \mathrm{~cm}^{2}$, this would suggest application of $>200$ pellets $\times 1.3$ $\mathrm{cm}^{2} / 143 \mathrm{~cm}^{2} \times 150 \mu \mathrm{m} / 10 \mu \mathrm{m}$, or $>30$ pellets per coverslip. However, because a higher rate of inertial impaction will occur in lower-generation airways, 40 was chosen as a first-order approximation.

Der p 1 was purified as described $(27,28)$ to $>98 \%$ (Figure 1). Enzymatic activity was measured spectrophotometrically using $N$-benzoyl-FVR-p-nitroanilide (single-letter amino acid notation). The activity of the aged fecal pellets used in Figures 2-4 was 17 nmol substrate degraded per minute; Der $\mathrm{p} 1$ enzyme activity in Figures 5 and 6 was $2.1 \mathrm{nmol}$ degraded per minute, with $3.1 \mathrm{nmol}$ degraded per minute in Figures 7-9 (amounts decreased deliberately to mimic airway exposures more closely), and $17 \mathrm{nmol}$ degraded per minute in Figure 10. Preparations were declared free of endotoxin by Limulus amebocyte lysis assay (ICN Pharmaceuticals Ltd., Basingstoke, United Kingdom).

Cell culture and permeability measurement. Cell culture and immunocytochemistry were performed as described $(24,29)$. Permeability of D- $\left[{ }^{14} \mathrm{C}\right]$ mannitol (Du Pont NEN, Brussels, Belgium) was measured (24) in confluent monolayers grown on a Matrigel undercoat in Transwells $(0.1-\mu \mathrm{m}$ pore diameter; Corning-Costar Ltd., High Wycombe, United Kingdom). Allergen preparations were diluted in EMEM for addition to cells. Controls comprised EMEM alone. Transepithelial movement of Der $\mathrm{p}$ 1 was measured by 2 -site ELISA using mAb $5 \mathrm{H} 8$ for coating and biotinylated $\mathrm{mAb} 4 \mathrm{Cl}$ (Indoor Biotechnologies, Chester, United Kingdom) for detection (30).

Immunostaining and 2-photon molecular excitation microscopy. TJs and desmosomes were viewed by fluorescent antibody staining using fluorescein dichlorotriazine (DTAF) or TRITC-labeled secondary antibodies (Vector Laboratories, Peterborough, United Kingdom; Chemicon International Ltd., Harrow, United Kingdom). ZO-1 was stained using mAb R40.76 (22); occludin was stained with MAb MOC37 (31); and desmoplakin was stained with mAb 11-5F (32). The 2photon molecular excitation microscopy (2PMEM) images were obtained using an LSM410 microscope (Carl Zeiss Ltd., Welwyn Garden City, United Kingdom) with titanium/sapphire mode-locked laser (Coherent Laser Group, Santa Clara, California, USA) excitation at $810 \mathrm{~nm}$, using 80- to 100-femtosecond pulses (33).

Quantitative analysis of 2PMEM images. Quantification was possible because 2PMEM imaging eliminated photobleaching of the specimens outside the focal plane, thereby providing a linear response. Measurements were made using programs written in IDL (Research Systems, Inc., Boulder, Colorado, USA). Three-dimensional isosurface reconstructions were prepared with IRIS Explorer (NAG, Oxford, United Kingdom). Analyses were performed on SGI Indigo2 and Indy workstations (Silicon Graphics, Reading, United Kingdom).

$\mathrm{TJ}$ proteins (ZO-1 or occludin) were quantified as fluorescence intensity (staining density) of the label at constant illumination power from the focal volume excited by the laser. Image stacks were read into computer memory as a 3-dimensional array, and the coordinates of cell boundaries were identified. The computer then searched for the most intense fluorescence near that X-Y coordinate in the image stack. Having found a start point, the staining pattern throughout the 3-dimensional data set was traced, voxel by voxel, to produce the coordinates that defined the periphery of the identified cell. The staining pattern normal to the traced coordinates was fitted by a Gaussian function to identify the peak fluorescence and its width in each cell. Breaks were defined as the number of times the staining intensity dropped below twice the average background intensity in adjacent voxels in the image stack along 

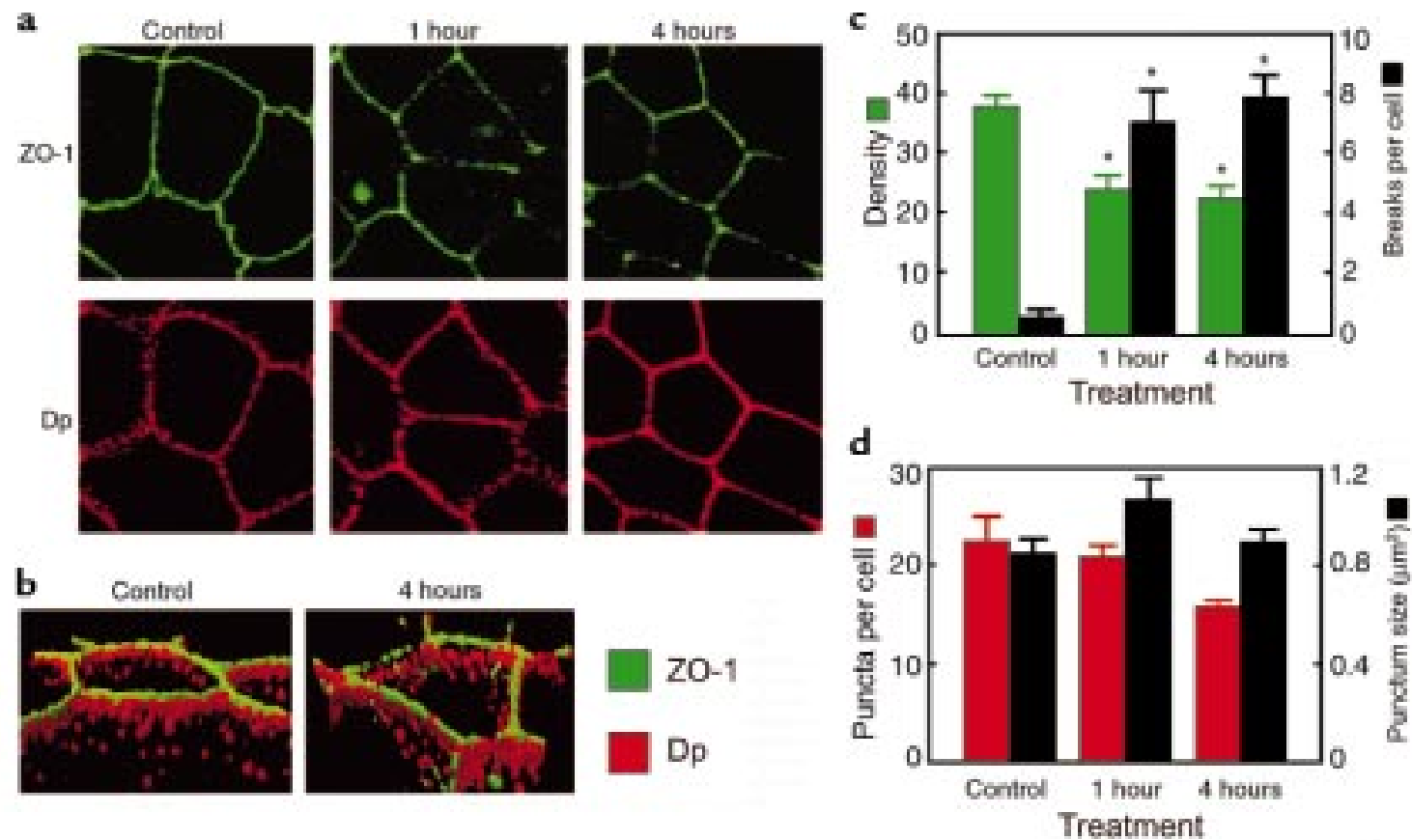

\section{Figure 2}

Effects of HDMFP on intercellular junctions of MDCK cells. (a) Sample through-focus images (2.8- $\mu \mathrm{m}$ thick) of ZO-1 and desmoplakin (DP) staining in control and after exposure to 40 solubilized fecal pellets apically applied for the periods indicated. (b) Isosurface-rendered images of the 3-dimensional distribution of ZO-1 (green) and desmoplakin (red) for a part of the image in a. Note the differential behavior of the 2 proteins. (c) Graphical analysis of immunoreactive ZO-1 concentration at the cell boundary and the number of breaks in the continuity of the ZO-1 staining belt per cell ( $\left.{ }^{*} P<0.05\right)$. Bars show mean \pm SE of 10 cells. (d) Quantification of desmoplakin staining.

the cell periphery. Data were reduced to measures of average fluorescence present in the periphery of each cell, the background fluorescence present, the number of breaks in the peripheral staining pattern, and the mean length of the break.

For desmosomal puncta, discrete staining sites were counted with a standard region-counting algorithm (IDL) from a binary mask constructed as follows. An unsharp mask filter was used to reject large-area variations in background intensity. The binary mask was then constructed by accepting regions of 3 or more connected pixels whose individual intensities were more than the mean +1 SD of the surrounding area $(10 \times 10$ pixels $)$.

Immunoblotting. Whole-cell extracts were prepared by washing cells $\left(3 \times 5 \times 10^{6}\right)$ twice with PBS containing 1 $\mathrm{mM}$ EGTA, $1 \mu \mathrm{g} / \mathrm{mL}$ aprotinin, $0.2 \mathrm{mM}$ 4-(2- a

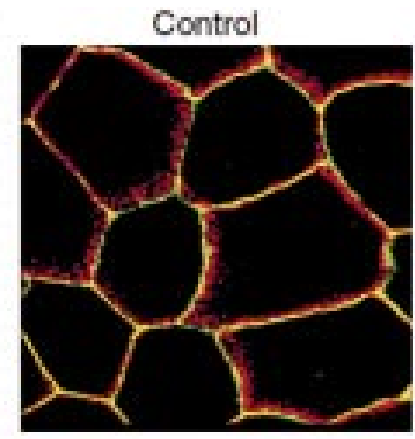

$X-Y$ direction

b

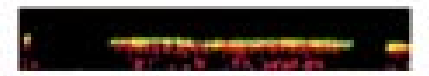

$\mathrm{X}-\mathrm{Z}$ direction
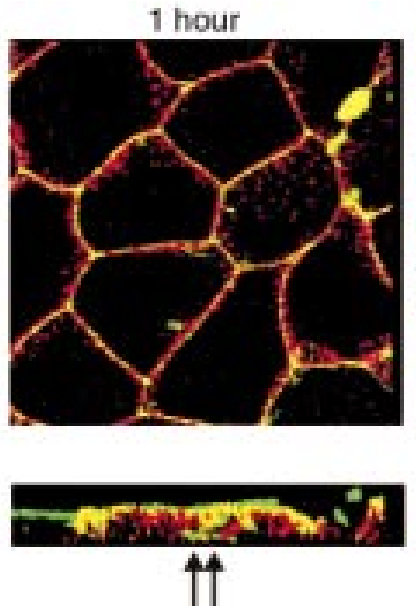

TJ displacement
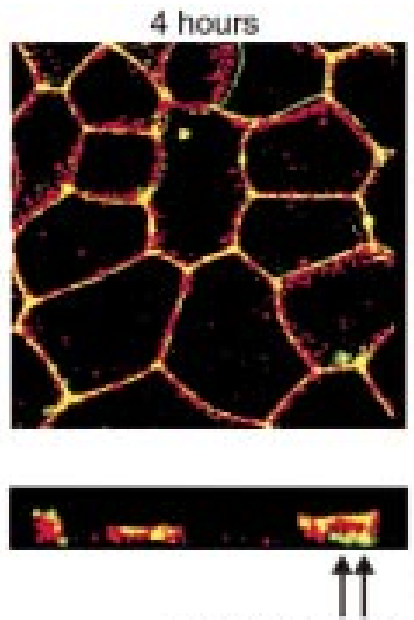

TJ displacement

Figure 3

Displacement of ZO-1 in MDCK cells treated with HDMFP as described in Figure 2. The images shown in a are 2-color, extended-focus X-Y sections in cells immunostained for ZO-1 (green) and desmoplakin (red), with the corresponding X-Z sections shown in b. Arrows indicate the areas of TJ displacement seen in cells 1 hour and 4 hours after treatment. 


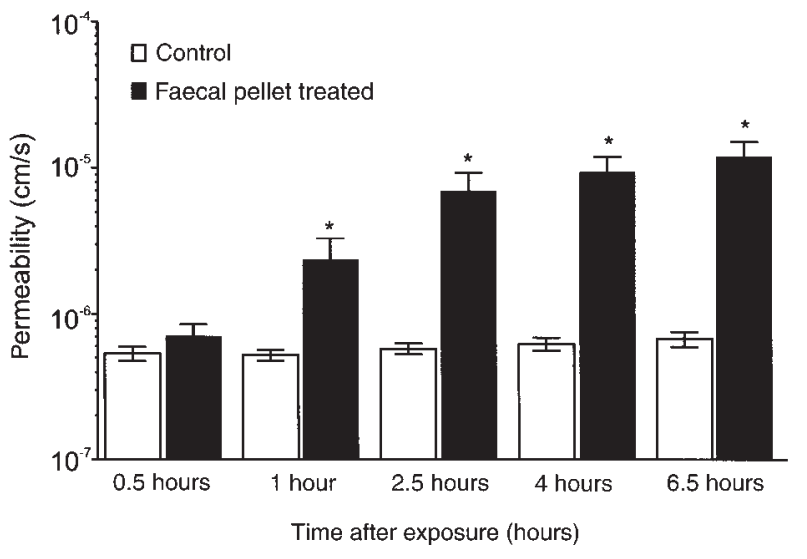

aminoethyl)-benzenesulphonyl fluoride hydrochloride (AEBSF), and $20 \mu \mathrm{M} \mathrm{E}-64$ [L-trans-epoxysuccinyl-leucylamide-(4-guanidino)-butane] (34). Boiling sample buffer (0.125 M Tris-HCl [pH 6.8], 4\% SDS, 20\% glycerol, $0.1 \mathrm{mg} / \mathrm{mL}$ bromophenol blue, $1.44 \mathrm{M}$ 2-mercaptoethanol) was added to the cells, and the lysate was scraped into an Eppendorf tube and boiled for 10 minutes. After SDS-PAGE, proteins were transferred electrophoretically to nitrocellulose membranes. Nonspecific binding was blocked with $5 \% \mathrm{wt} / \mathrm{vol}$ nonfat milk

\section{Figure 4}

Time-dependent effects of HDMFP on the mannitol permeability of MDCK cell monolayers cultured in Transwells. Forty HDMFPs solubilized in EMEM containing $0.5 \mathrm{mM}$ of reduced glutathione were added to monolayers (filled bars). Open bars show monolayers sham treated with EMEM/glutathione alone. Data are mean \pm SE of 4 experiments. ${ }^{*}$ Significant differences from sham-treated monolayers $(P<0.05)$.
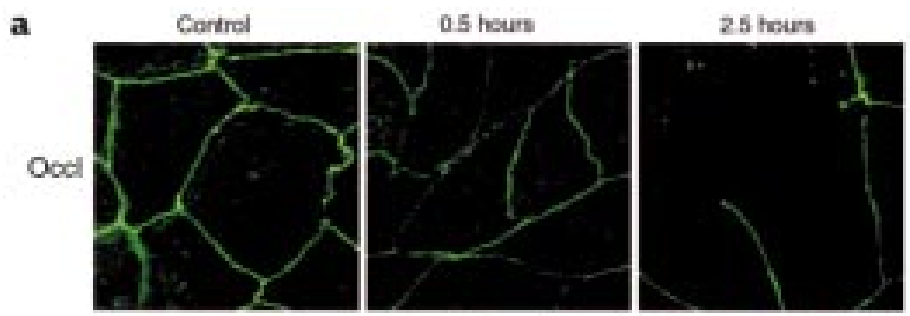

b
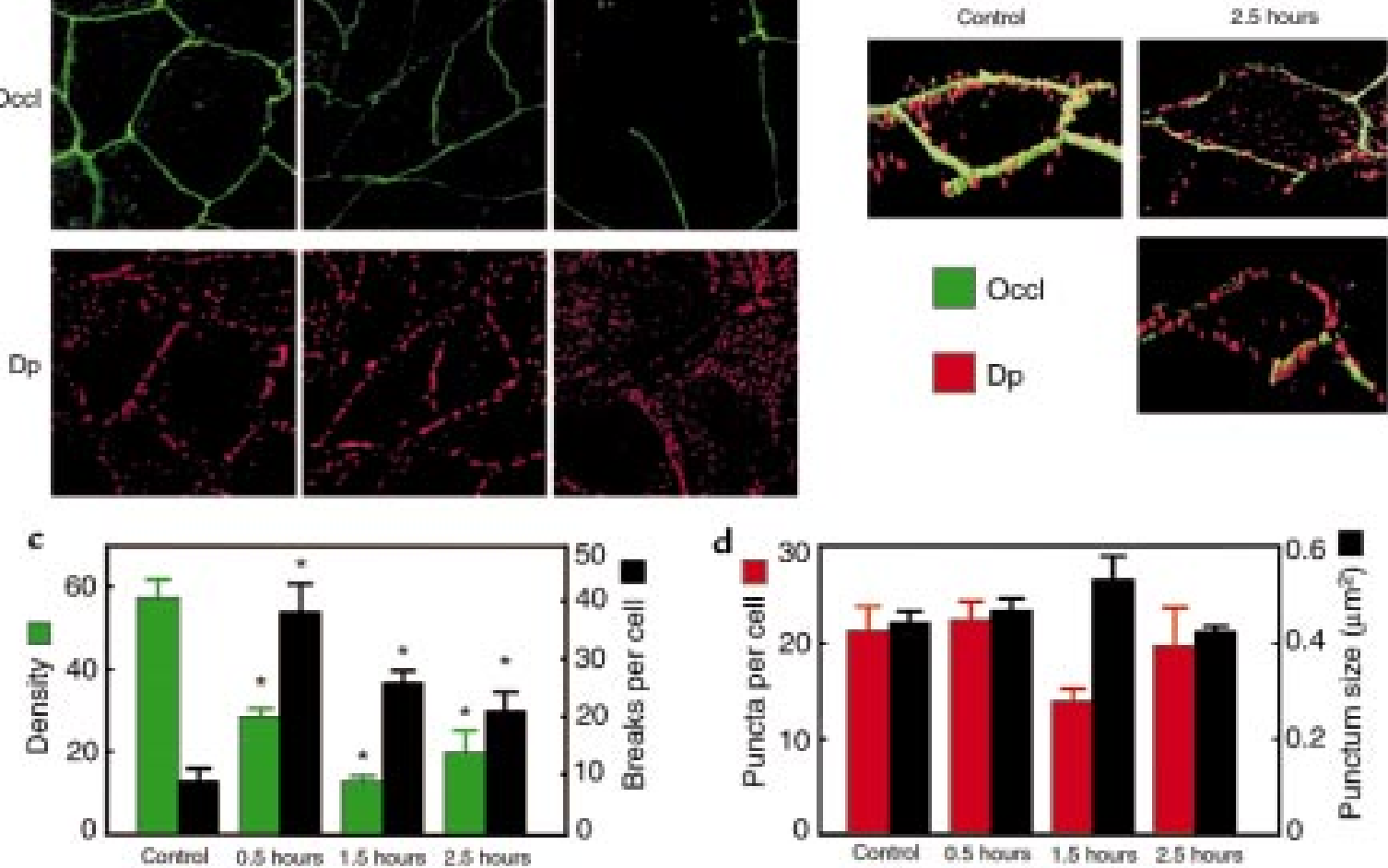

Figure 5

Effects of purified Der $\mathrm{p} 1$ on intercellular junctions of $16 \mathrm{HBE} 14 \mathrm{o}^{-}$cells. (a) Sample through-focus images (3.2- $\mu \mathrm{m}$ thick) of occludin and desmoplakin staining in control and after exposure of the apical surface to Der $p 1$ for the periods indicated. The effects are similar to that seen in Figure 2a. (b) Isosurface-rendered images of the 3-dimensional distribution of occludin (Occl; green) and desmoplakin (Dp; red) for a part of the image in a. The left panel shows a typical untreated cell, whereas the 2 panels on the right show the heterogeneity of response after 2.5 hours. (c) Graphical analysis of occludin concentration and the number of breaks in continuity of the occludin ring per cell. Bars show mean and $+\mathrm{SE}$ of 8 cells $\left({ }^{*} P<0.05\right)$. The method of measurement was the same as for Figure $2 \mathrm{c}$. (d) Quantification of desmoplakin staining. 
whole-cell protein extracts were separated electrophoretically. A section of gel containing high- and low-mass occludin (60-80 kDa) was excised and treated (35) with Der $p 1$ for 30 minutes during stacking, before a second round of electrophoresis and immunoblotting.

Peptide HPLC/electrospray ionization mass spectrometry. Peptides $(650 \mu \mathrm{g} / \mathrm{mL})$ and Der $\mathrm{p} 1$ were incubated in $50 \mathrm{mM}$ Tris-HCl buffer/0.6mM DTT (pH 7.2) at $37^{\circ} \mathrm{C}$. Samples $(15 \mu \mathrm{L})$ were taken at predetermined time points, mixed with $5 \mu \mathrm{L} 10 \% \mathrm{vol} / \mathrm{vol}$ trifluoroacetic acid (TFA) and injected onto a Lichrospher RP-18 HPLC column $(150 \mathrm{~mm} \times 3 \mathrm{~mm})$. Elution was at 0.5 $\mathrm{mL} / \mathrm{min}$ for 30 minutes in a linear gradient of $10-60 \%$ acetonitrile in water containing $0.04 \%$ TFA (Waters 616 pump with 486 tunable absorbance detector monitoring $\mathrm{A}_{280 / 260}$; Waters Ltd., Watford, United Kingdom). After a 4-minute flow diversion to remove the solvent front, the eluate was directed with a 10:1 stream split into the electrospray source of a VG Quattro II mass spectrometer (Micromass Ltd., Manchester, United Kingdom). Positive-ion spectra were acquired over the mass range $220-1,350 \mathrm{kDa}$ every 3 seconds. Masses of the protonated species of potential cleavage fragments were used to identify reaction products. Peptides were 8- to 12-mer sequences from the extracellular loops of occludin and claudin-1, and were custom synthesized by Genosys Biotechnologies (Pampisford, United Kingdom).

Statistical analyses. Statistical significance, calculated using the Statistica program suite (Statsoft Inc., Tulsa, Oklahoma, USA), was taken as $P<0.05$.

\section{Results}

HDMFPs disrupt TJs and increase permeability. Application of 40 hydrated HDMFPs to confluent MDCK epithelial monolayers altered the staining pattern of ZO-1 (Figure 2). Normally, TJs, as identified by ZO-1 immunostaining, form a continuous ring that circumscribes each cell. TJ rings became broken after 1 hour of HDMFP exposure. After 4 hours, TJ disruption was extensive, and some cells detached from the substratum, creating "holes" in the monolayer. Changes were more marked for ZO-1 than for desmoplakin, whose general appearance was not obviously altered (Figure 2a). Figure 2b depicts the 3 -dimensional staining pattern contained within the extended-focus images of Figure 2a. Clearly, 4-hour exposure to HDMFPs produced TJ breakage. Similar results were obtained in every experiment $(n=8)$, suggesting that a major disruption of $\mathrm{TJ}$ integrity had occurred. Digital image analysis (Figure 2, c and d) showed significant increases in the number of $\mathrm{TJ}$ breaks per cell and a significant reduction in the density of ZO-1 staining, suggesting a loss of protein from TJs. The number of desmoplakin staining sites decreased only after a 4-hour treatment, without an obvious trend in the size of the desmoplakin puncta. Identical data were obtained in $16 \mathrm{HBE}^{-14 \mathrm{o}^{-}}$cells (not shown). In addition to the gross disruption of TJs (Figure 2, a
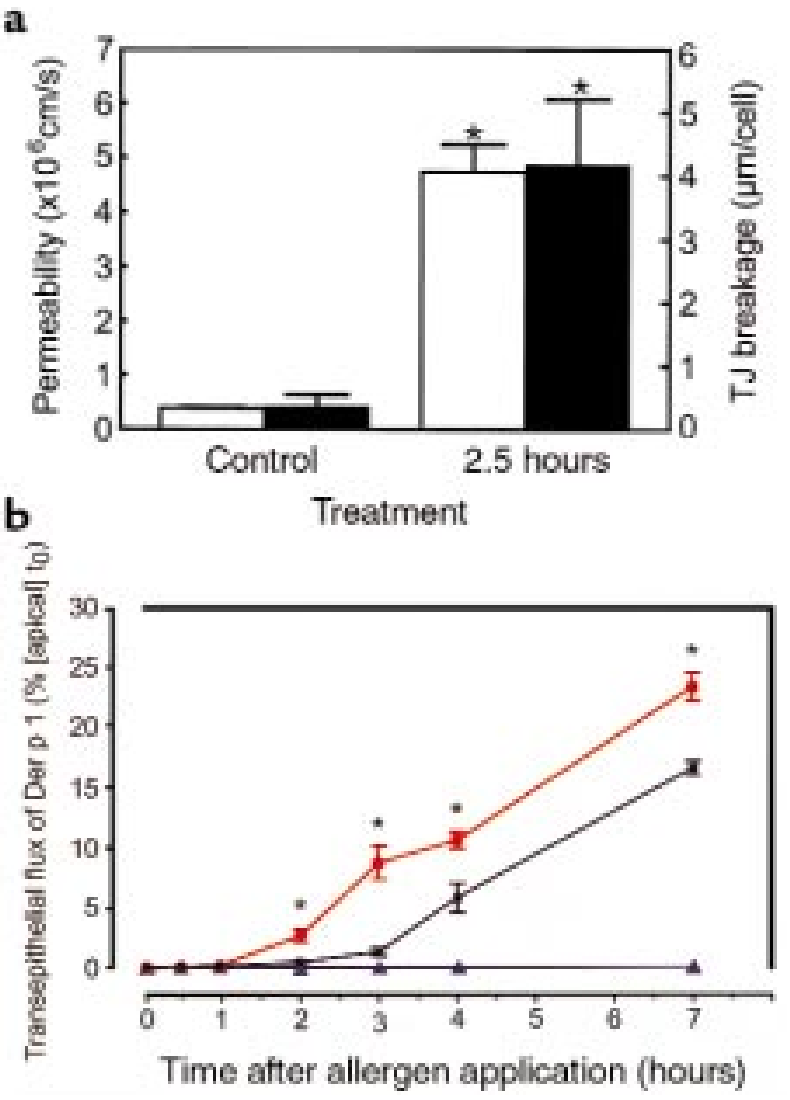

Figure 6

Effects of Der 1 on permeability of MDCK cell monolayers. (a) Concordance between changes in $\left[{ }^{14} \mathrm{C}\right]$ mannitol permeability (open bars) and TJ breakage (i.e., the total length of breaks per cell; filled bars) in the same cell monolayer. Data are mean $\pm \mathrm{SE}$ from 4 experiments $\left({ }^{*} P\right.$ $<0.05)$. (b) The migration of immunoreactive Der $p 1$ across MDCK cell monolayers depends upon enzymatic activity. Data are expressed as the percentage of the starting concentration ([apical] $t_{0}$ ) of Der $p$ 1 in the apical compartment that was detected in the basal chamber at the indicated time points. Data in red denote monolayers treated with catalytically active allergen; black denotes cells treated with active allergen in the presence of E-64 $(100 \mu \mathrm{M})$; and blue denotes cells treated with heat-inactivated allergen. Data are mean \pm SE from 5 experiments. ${ }^{*}$ Responses significantly different from both of the other treatments $(P<0.05)$. At 7 hours, the transepithelial flux of Der $p 1$ was 168 -fold greater in monolayers exposed to active Der $p 1$ compared with those exposed to inactive Der $\mathrm{p} 1$.

and b), some $\mathrm{ZO}-1$ was displaced basally from its normal position apical to desmosomes (11), retaining its peripheral localization. This displacement of ZO- 1 is suggested in the 3 -dimensional reconstruction (Figure $2 \mathrm{~b}$ ) and by the $\mathrm{X}-\mathrm{Z}$ sections (Figure 3 ).

Permeability measurements were made to determine whether the effects of HDMFP on TJs might be associated with a diminished epithelial barrier. Figure 4 shows that increasing permeability of MDCK monolayers reflected the progression of TJ disruption. Shamtreated monolayers were unaffected (Figure 4).

Purified Der $p 1$ leads to TJ breakage. Separation of HDMFP extracts into various fractions yielded a partially purified active principle enriched in Der $\mathrm{p} 1$. This 

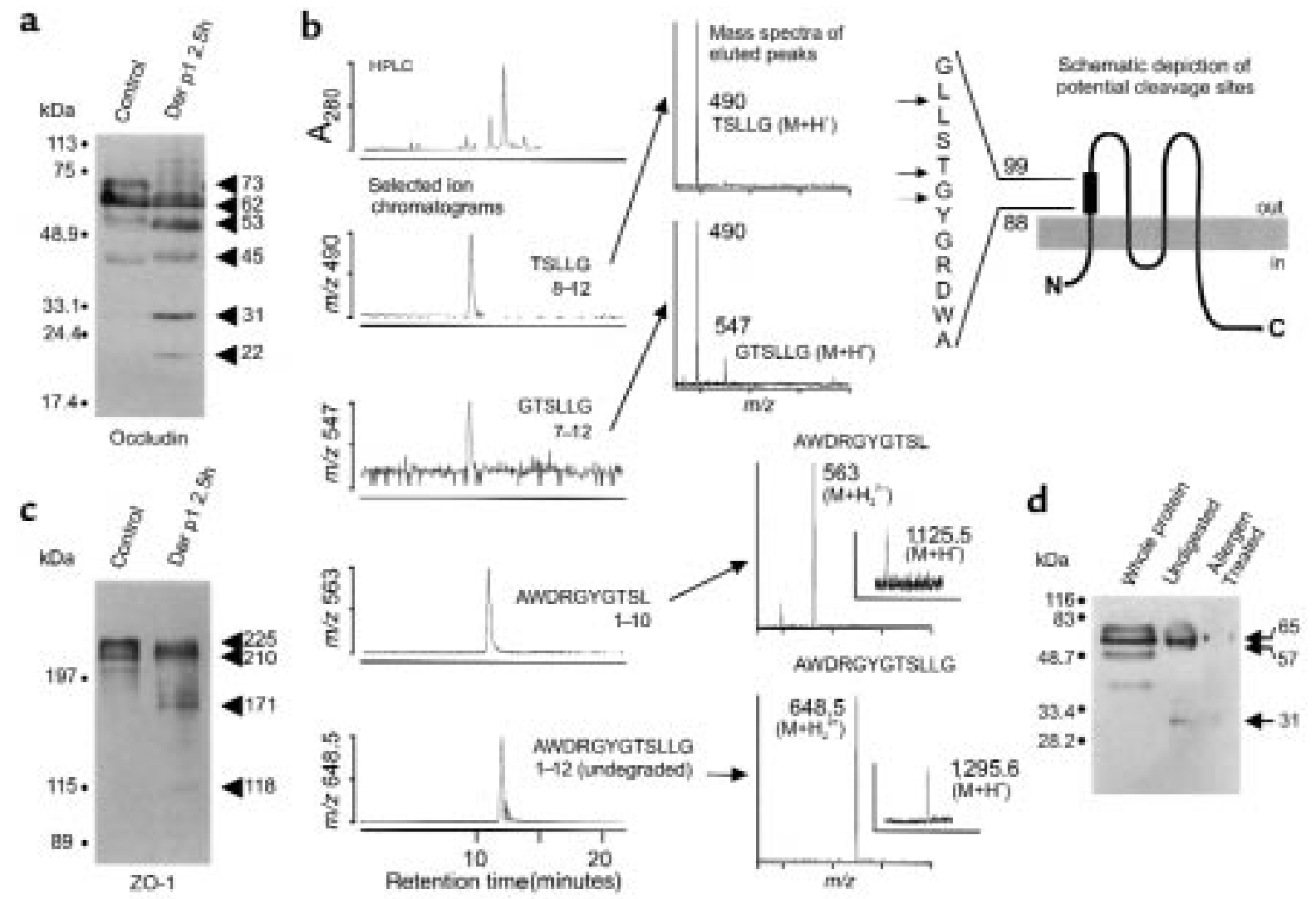

Figure 7

Proteolysis of occludin in situ, occludin extracellular loop peptide, ZO-1 in situ, and gel-enriched occludin by Der p 1. (a) Immunoblots of occludin from $16 \mathrm{HBE} 14 \mathrm{o}^{-}$cells prepared from sham-treated cells and after a 2.5 -hour exposure to Der $p 1$. (b) Degradation by Der $p 1$ of peptide ${ }^{88}$ AWDRGYGTSLLG ${ }^{99}$ corresponding to residues 88-99 of human occludin (top right), with identified cleavage sites marked by arrows. The left section of $\mathbf{b}$ shows the HPLC $A_{280}$ chromatogram and selected ion chromatograms for the 4-hour incubation products of Der $\mathrm{p} 1$ with the peptide. Mass spectra for the peptides are shown. Major components correspond to unchanged 12-mer sequences $\left(\mathrm{M}+\mathrm{H}^{+}\right.$, $m / z$ 1,295.6; $\mathrm{M}_{+} \mathrm{H}_{2}{ }^{2+}, m / z$ 648.5) and residues 1-10 $\left(\mathrm{M}+\mathrm{H}^{+}, m / z 1,125.5 ; \mathrm{M}+\mathrm{H}_{2}{ }^{2+}, m / z 563\right), 7-12\left(\mathrm{M}+\mathrm{H}^{+}, m / z\right.$ 547), and 8-12 (M+H $\mathrm{H}^{+}, m / z$ 490). (c) Immunoblots showing degradation of ZO-1 after 2.5-hour exposure of 16HBE14o- cells to active Der $\mathrm{p} 1$. (d) Immunoblot showing degradation of gel-enriched human occludin by allergen. Lanes show whole-cell protein extract (Whole protein), and gel-enriched occludin without allergen treatment (Undigested) and with treatment (Allergen treated).

mimicked the events above in both MDCK and $16 \mathrm{HBE} 14 \mathrm{o}^{-}$cells (not shown), and could be inhibited by the cysteine proteinase inhibitor E-64. Because the amino acid sequence of Der $\mathrm{p} 1$ implies that it is a cysteine proteinase, these observations suggested that Der p 1 might be the active principle. To test this, we prepared pure Der $\mathrm{p} 1$. Figure 5, a and b illustrate the effect of pure Der $\mathrm{p} 1$ on $16 \mathrm{HBE} 14 \mathrm{o}^{-}$cells immunostained for occludin. The response to Der $\mathrm{p} 1$ is similar to that shown in Figure 2. Quantitative reductions in TJ continuity and occludin content were found (Figure 5c). No significant changes occurred in either the number or size of desmoplakin puncta (Figure $5 \mathrm{~d}$ ). Immunostaining of ZO-1 in MDCK cells was also disrupted by Der $p 1$, confirming the reciprocity of these effects on $\mathrm{TJ}$ proteins in the 2 cell lines (data not shown).

Purified Derp 1 increases permeability. Figure 6a shows that the alteration in $\mathrm{TJ}$ structure after a 2.5 -hour exposure to Der $\mathrm{p} 1$ produced an $\sim 12$-fold increase in mannitol permeability, indicating that $\mathrm{TJ}$ breakage (Figure 6a, filled bars) is associated with a loss of TJ integrity. These changes were due to the enzymatic activity of Der $p 1$, because neither oxidized nor heatinactivated Der $p 1$ had any effect. Figure $6 \mathrm{~b}$ shows that $\mathrm{TJ}$ breakage led to a transepithelial migration of the allergen that was inhibitable by E-64. Furthermore, the ability of heat-inactivated Der $\mathrm{p} 1$ to cross the monolayer was $<1 \%$ that of catalytically active Der $\mathrm{p} 1$ after a 7-hour treatment (Figure 6b).

Derp 1 leads to occludin cleavage. Occludin was detected in immunoblots at $\sim 62-65 \mathrm{kDa}$, with less intense forms at $\sim 70-75 \mathrm{kDa}$ (Figure 7a). After exposure of cells to Der $\mathrm{p}$ 1 , occludin was partially cleaved into products of decreased molecular mass $(\sim 53 \mathrm{kDa}, \sim 31 \mathrm{kDa}$, and $\sim 22$ $\mathrm{kDa}$ ). A 45-kDa band was detected in both control and Der $\mathrm{p} 1$-treated cells. To address whether Der $\mathrm{p} 1$ cleavage sites exist within extracellular domains of occludin, we used HPLC/electrospray mass spectrometry to analyze the products formed by reacting pure Der $\mathrm{p} 1$ with synthetic peptide segments of the occludin loop sequences. ${ }^{88}$ AWDRGYGTSLLG ${ }^{99}$, of the first extracellular loop of human occludin, underwent facile cleavage of LL (prod- 

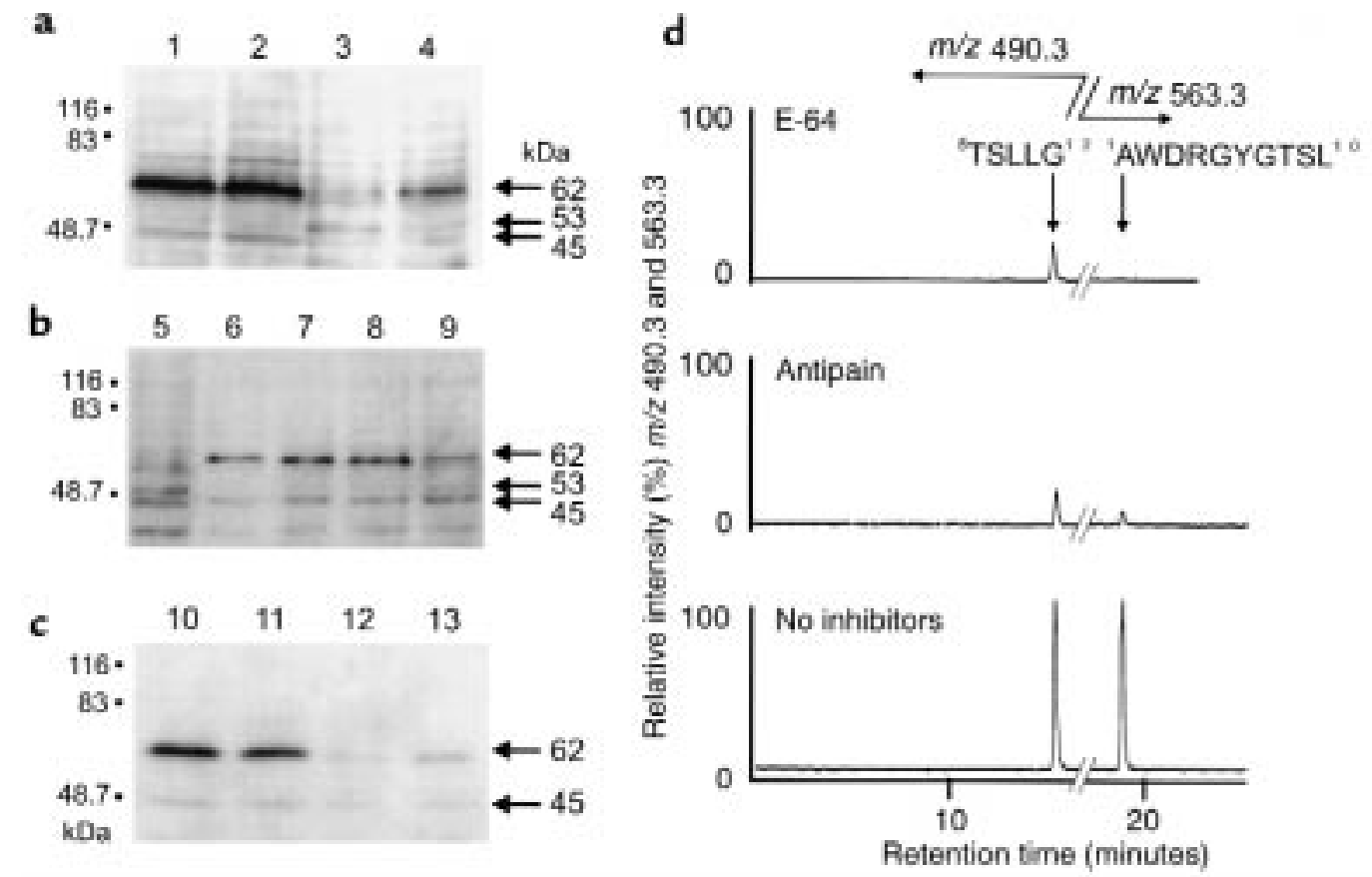

\section{Figure 8}

(a) Occludin immunoblots from MDCK cells. Lane 1: untreated cells; lane 2: cells treated with heat-inactivated Der p 1 for 1 hour; lane 3: following 1-hour treatment with active Der p 1 (activity $17 \mathrm{nmol} / \mathrm{min}$ ); lane 4: active Der p 1 with $100 \mu \mathrm{M}$ antipain. Note attenuation of degradation by antipain or heat inactivation. (b) Inhibition of occludin degradation in MDCK cells by occludin peptide ${ }^{88}$ AWDRGYGTSLLG ${ }^{99}$. Lane 5: cells treated for 1 hour with Der $p$ 1; lane 6: peptide $(100 \mu \mathrm{M})$ and cells alone; lanes 7-9: cells treated with peptide and Der $p 1$ for 0.25 , 0.5 , and 1 hour, respectively. (c) Lack of effect of mixed proteinase inhibitors on occludin degradation in MDCK cells treated with Der $p 1$. Lane 10: untreated cells; lane 11: mixed inhibitors (100 $\mu \mathrm{M}$ AEBSF, $1 \mu \mathrm{M}$ BB-250, and $1 \mu \mathrm{M}$ pepstatin) alone; lane 12 : Der $\mathrm{p} 1$ alone; lane 13: Der $\mathrm{p} 1$ with mixed inhibitors. (d) HPLC/electrospray-selected ion mass chromatograms for $m / z 490.3\left(\mathrm{M}+\mathrm{H}^{+}\right.$, GTSLLG) and $m / z 563.3$ $\left(\mathrm{M}+\mathrm{H}_{2}{ }^{2+}\right.$, AWDRGYGTSL) are shown following Der 1 treatment of AWDRGYGTSLLG in the presence of E-64 (100 $\left.\mu \mathrm{M}\right)$, antipain (100 $\left.\mu \mathrm{M}\right)$, or the absence of inhibitors. Both inhibitors reduced the formation of 2 major enzymic fragments, AWDRGYGTSL and GTSLLG.

uct AWDRGYGTSL). Attack of GT (product TSLLG) and YG bonds (product GTSLLG) also occurred (Figure 7b).

Figure 7c shows that ZO-1 also underwent proteolysis, indicating that the response to Der $\mathrm{p} 1$ also involved activation of intracellular protein processing. The effects of Der $p 1$ were mimicked by apical application of papain (substrate-degrading activity $5.4 \mathrm{nmol} / \mathrm{min}$ ) to MDCK cells for 2.5 hours, which increased mannitol permeability from $0.35 \pm 0.11 \times 10^{-6} \mathrm{~cm} / \mathrm{s}$ to $9.30 \pm$ $1.70 \times 10^{-6} \mathrm{~cm} / \mathrm{s}(n=3, P<0.05)$. Immunoblotting revealed similar profiles of cleavage in occludin and ZO-1 as in Der p 1 (not shown).

To support the view that Der $\mathrm{p} 1$ degrades occludin, gel-enriched high- and low-mass occludin were treated with Der $\mathrm{p} 1$. The ensuing loss of occludin suggested that degradation could be catalyzed directly (Figure 7d).

Heat-inactivated Der $\mathrm{p} 1$ had no effect on occludin in MDCK cells, whereas degradation was extensive with active Der p 1 (Figure 8a). The cysteine proteinase inhibitor antipain retarded the action of Der $\mathrm{p} 1$ (Figure $8 \mathrm{a}$ ), as did the occludin loop peptide (Figure 8b). Cysteine proteinase inhibitors and occludin peptide also inhibited the allergen-dependent loss of TJ immunostaining and the permeability change in epithelial monolayers (not shown). However, the cellular response to Der p 1 was not inhibited by AEBSF, pepstatin, and [4-( $N$-hydrox-
yamino)-2R-isobutyl-3S-(thiophen-2-yl-sulphonylmethyl)succinyl]-L-phenylalanine- $N$-methylamide (BB250), (Figure 8c), suggesting that serine, aspartic, and matrix metall- oproteinases play little role in the extracellular processing of occludin following Der $\mathrm{p} 1$ exposure. The evidence presented in Figure 8 also supports degradation of the occludin peptide by Der $\mathrm{p} 1$ being due to cysteine proteinase activity, because the facile cleavages of LL and GT were attenuated by antipain and E-64 (Figure $8, \mathrm{~d}$ and e). These changes were accompanied by increases in the amounts of undegraded substrate.

Der $p 1$ cleavage sites may exist in claudin-1. Reaction of Der $\mathrm{p} 1$ with ${ }^{64} \mathrm{KVFDSLLNLNS}{ }^{74}$ from the first extracellular loop of murine claudin-1 yielded facile cleavage of LL (products KVFDSL and LNLNS) and NL (product KVFDSLLN). Scission of LN also occurred (product KVFDSLLNL) (Figure 9). ${ }^{138}$ WYGNRIVQ ${ }^{144}$ (second extracellular loop) underwent facile cleavage of GN (products WYG and NRIVQ) (Figure 9), with evidence of a minor reaction at YG (not shown).

Recovery of TJs after Der $p 1$ exposure. Cells whose TJs had been extensively disrupted by Der $\mathrm{p} 1$ recovered following its removal (Figure 10, a and b). Within 1 hour, a reticular pattern of ZO-1 was forming (Figure 10b). Reestablishment of occludin rings was slower (Figure 10a) but did eventually progress to completion. 
$\mathbf{a}$

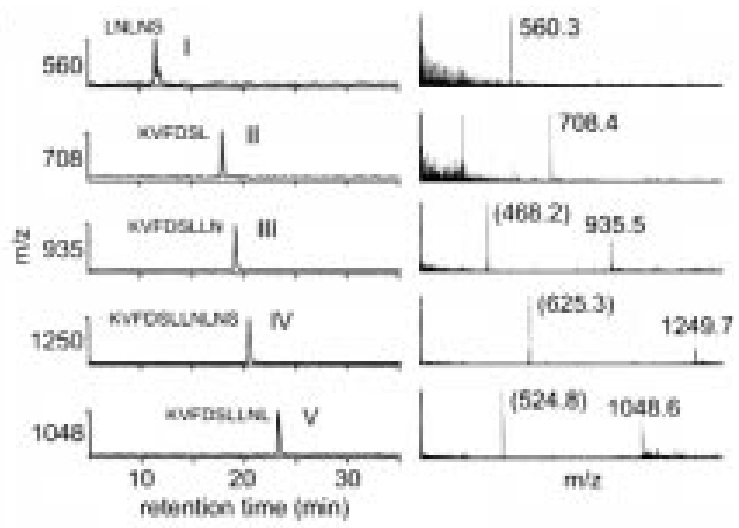

b
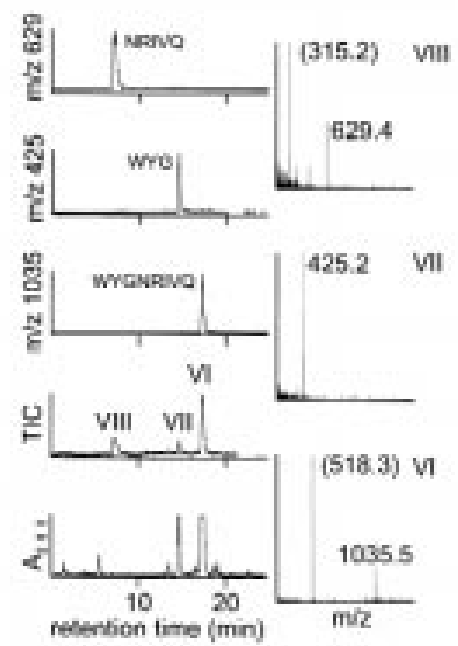

c

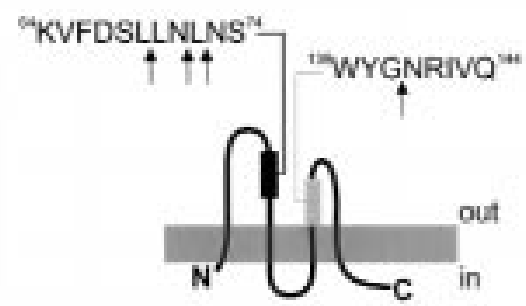

\section{Figure 9}

Potential Der $\mathrm{p} 1$ cleavage sites in claudin-1 extracellular loops. (a) Digestion of ${ }^{64} \mathrm{KVFDSLLNLS}{ }^{74}$ (peptide IV) for 2 hours resulted in 4 major peptides. The HPLC/electrospray-selected ion chromatograms are shown in the left section. I: LNLNS; II: KVFDSL; III: KVFDSLLN; and V: KVFDSLLNL. Peptides II-V were associated with $\mathrm{A}_{260}$ ultraviolet absorbance. Unchanged peptide was the major species in the total ion current (TIC) (not shown). Mass spectra for the peptides are shown on the right. Each peptide generated an $\mathrm{M}+\mathrm{H}^{+}$ion as shown. Larger peptides (III-V) produced intense doubly charged ions $\left(\mathrm{M}+\mathrm{H}_{2}{ }^{2+}\right.$, bracketed); the molecular ion regions of these spectra were magnified 2- to 4-fold for display. (b) Digestion of ${ }^{138}$ WYGNRIVQ ${ }^{144}$ (peptide VI) generated 2 major fragments, WYG (VII) and NRIVQ (VIII). Small amounts of other fragments were observed. The HPLC $\mathrm{A}_{280}$ ultraviolet absorbance chromatogram is shown together with electrospray mass chromatograms for the TIC and ion channels $\mathrm{m} / \mathrm{z}$ $1,035,629$, and 425. Mass spectra for VI-VIII are shown at the right; doubly charged ions are bracketed; and the molecular ion region of VI has been magnified for display. (c) Schematic representation of putative cleavage sites within claudin-1. The shaded boxes superimposed on the extracellular domains show approximate locations of the cleavable segments depicted. Arrows indicate cleavage sites identified in peptides. Residue numbering from murine claudin- 1 .

\section{Discussion}

Our results suggest an entirely novel view of the sensitization to HDM allergens: the intrinsic proteolytic activity of the allergen leads to degradation of TJs in airway epithelium, thus increasing the accessibility of the sentinel dendritic antigen-presenting cells residing beneath the epithelial barrier. Specifically, the HDM allergen Der $\mathrm{p} 1$ leads to cleavage of the TJ membrane protein occludin, suggesting a major role for the allergen in decreasing the effectiveness of the epithelial barrier.

That Der $\mathrm{p} 1$ is a proteinase has been indicated previously $(6,21,24,36-42)$. We reasoned that its proteolytic effects in airway epithelium might be significant to sensitization because of the degree to which airway mucosal barrier is exposed to foreign proteins. Small amounts of HDMFP or pure Der $\mathrm{p} 1$ caused TJs to break and become displaced from their normal position apical to desmosomes (11). Whereas the effects of HDMFPs on epithelial cells were mediated by $8-10 \mathrm{ng}$ of Der $\mathrm{p} 1$ protein ( 1 fecal pellet contains $\sim 0.2 \mathrm{ng}$ of Der $\mathrm{p} 1$ ), the proteolytic effects of Der $\mathrm{p} 1$ described in other cells require microgram amounts $(40,41)$. Moreover, because Der $p 1$ is a cysteine proteinase susceptible to oxidation, with irreversible loss of catalytic activity, our deliberate aging of HDMFPs means that the catalytically effective amount of Der $\mathrm{p} 1$ delivered to the cell surface was probably somewhat less than 8-10 ng. Thus, our findings indicate that epithelial cells could be the primary proteolytic targets of Der $\mathrm{p} 1$ in vivo, because they are the cells most likely to be exposed to the highest concentrations of inhaled allergens.

Another novel aspect of our study is the use of 2PMEM to quantify TJ proteins in situ. Using 2 PMEM enabled us to correlate the time-dependent decrease of both occludin and ZO-1 with the increase in epithelial permeability and with cleavage of these proteins, as shown by immunoblotting. We thus established a link between allergen proteinase activity and diminished effectiveness of the epithelial barrier.

Occludin was expressed predominantly in a 62- to 65$\mathrm{kDa}$ form, with possibly phosphorylated $(31,43)$ forms at $\sim 70-75 \mathrm{kDa}$. The $70-75-\mathrm{kDa}$ band was evident in $16 \mathrm{HBE}^{14 \mathrm{o}^{-}}$cell extracts blotted with polyclonal antibody, but less visible in MDCK cell extracts blotted with MOC37. In 16HBE14o ${ }^{-}$cells exposed to pure Der $\mathrm{p} 1$, both high- and low-mass forms were reduced in intensity. We can conclude that the cleavage products detected all contain the $\mathrm{COOH}$-terminal of occludin, because the blotting antibody recognizes a 150-residue $\mathrm{COOH}$-terminal segment. Inspection of the occludin sequence and prediction of its membrane topography using the program SOSUI (44) suggest that the 53-kDa occludin product arises by cleavage within the first external loop. The accessibility of this loop to exogenous macromolecules is demonstrated by occludin immunostaining in nonpermeabilized CaCo- 2 cells (19), using antibodies against the segment of the first extracellular loop in which we report putative cleavage sites. Furthermore, as cleavage proceeds, steric hin- 
a

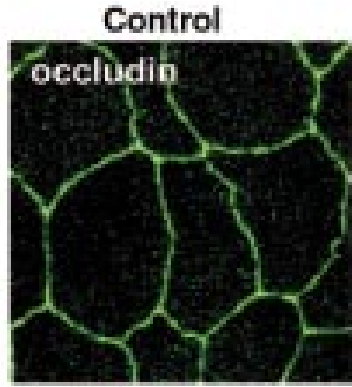

$\mathrm{X}-\mathrm{Y}$ direction

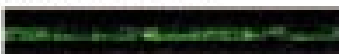

$\mathbf{X}-\mathbf{Z}$ direction
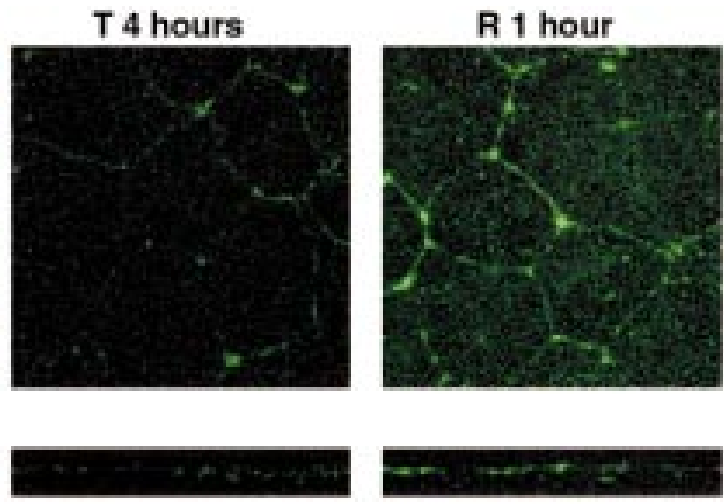

R 16 hours
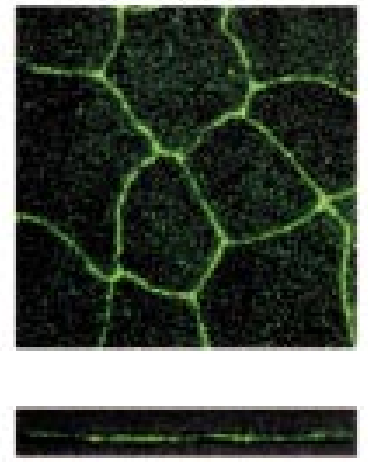

b

Control

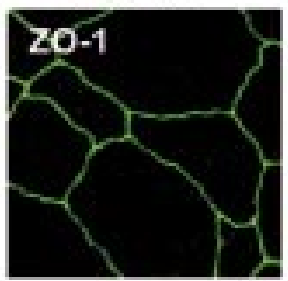

$\mathrm{X}-\mathrm{Y}$ direction

$\mathrm{X}-\mathrm{Z}$ direction
T 4 hours
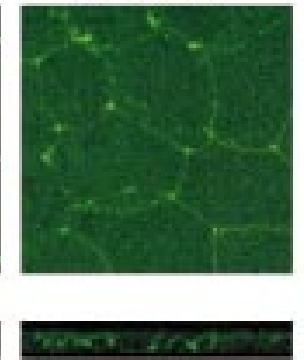

R1 hour

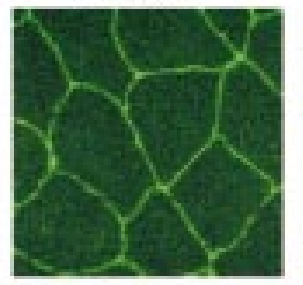

R 3 hours

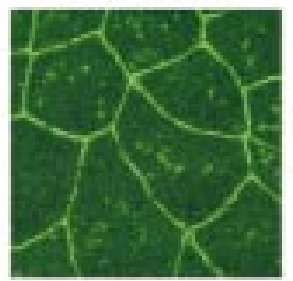

R 16 hours

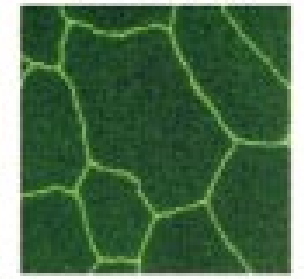

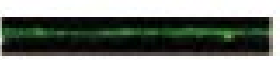
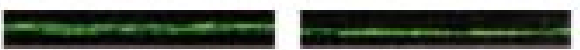

Figure 10

Recovery of occludin and ZO-1 in 16HBE140- epithelial cell monolayers following exposure to Der p 1. Cells were sham exposed (control) or treated with allergen for 4 hours ( $T 4$ hours), and then changed to normal medium for recovery (R 1 hour, R 3 hours, R 16 hours). Images are shown as extended-focus $X-Y$ sections with the corresponding $X-Z$ images.

drance provided by the TJ itself would minimize, so that the velocity of TJ disassembly should increase progressively. In contrast to the above, the $31-\mathrm{kDa}$ and $22-$ $\mathrm{kDa}$ occludin products are probably derived by intracellular processing, because their masses are consistent with the $\mathrm{COOH}$-terminal domain alone.

Two general possibilities could explain the extracellular cleavage of occludin. Either Der p 1 is envisaged to cleave occludin directly or Der $\mathrm{p} 1$ might activate a cell surface zymogen that then degrades occludin. Experiments favor the more direct option: (a) the immunoblotting evidence and identification of putative Der $\mathrm{p} 1$ cleavage sites in a synthetic peptide strongly suggest that the first extracellular loop of occludin may be considered a substrate of Der p 1; (b) an occludin loop peptide itself acted as an inhibitor of occludin degradation in situ; (c) the failure of serine, aspartic, and metalloproteinase inhibitors to block the in situ degradation of occludin by Der $\mathrm{p} 1$ argues against the existence of an extracellular proteolytic cascade involving enzymes of these families.

Until recently (18), occludin was the only known transmembrane protein of TJs. Despite the proposal that claudin- 1 and -2 may be more significant in TJ structure (20), functional evidence indicates that disruption of occludin causes epithelial barriers to fail. Peptides mimicking extracellular loops of occludin open TJs (45) and prevent the gain of adhesiveness in occludin-null cell lines transfected with occludin (19). These results would not be expected if occludin were of secondary importance in TJ structure and function. Our data provide clear evidence that Der $p 1$ increases epithelial permeability and disrupts TJs. The inescapable conclusion is that occludin and all other $\mathrm{TJ}$ adhesion proteins that regulate paracellular permeability must be affected in this process, and that initiation of the response ultimately depends upon the proteolytic activity of Der $\mathrm{p} 1$.

Potential Der $\mathrm{p} 1$ cleavage sites exist in both extracellular loops of claudin-1. In ${ }^{64} \mathrm{KVFDSLLNLNS}^{74}$ cleavage of LL was facile (as seen in occludin). This suggests that like papain (46), Der $\mathrm{p} 1$ exhibits a $\mathrm{P}_{1}{ }^{\prime}$ preference for hydrophobic residues. Other cleavages, especially of YG in occludin and in loop 2 of claudin-1, were less facile. Interestingly, the facile LL cleavage site of claudin- 1 is replicated in 5 of the 8 known claudins (47), whereas in claudins 4,5 , and 7 the equivalents of $\mathrm{P}_{1}{ }^{69} \mathrm{~L}$ are conservative substitutions $(\mathrm{M}, \mathrm{V}, \mathrm{V})(47)$. Collectively, these observations suggest that occludin and claudins are all targets of Der $\mathrm{p} 1$ and that there may be a preference for small, uncharged polar residues at $\mathrm{P}_{2}$ in its natural mammalian substrates.

In addition to cleavage of occludin, ZO-1 (22) was degraded following exposure of cells to HDMFPs or Der p 1. Because ZO-1 is intracellular $(9,16,22)$, and 


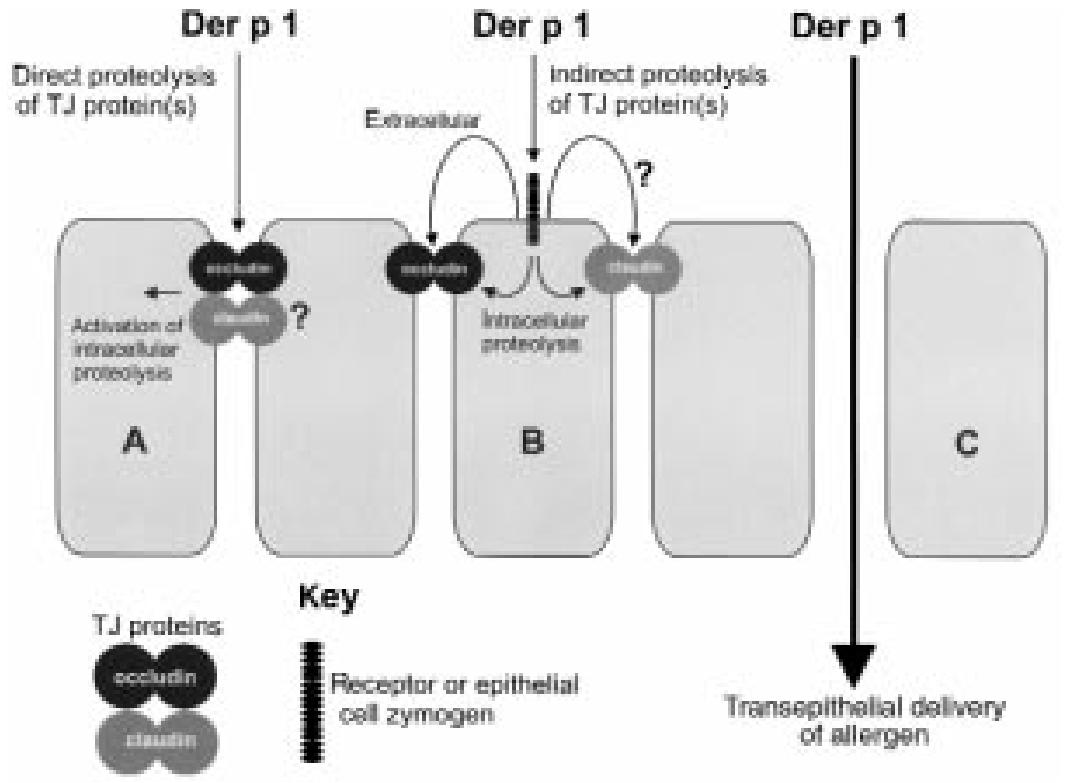

\section{Figure 11}

Schematic summary of how Der $p 1$ might open TJs in lung epithelium. In the simple case, cell A, Der $p 1$ acts upon extracellular loops of occludin, and possibly claudin-1. Extracellular cleavage of TJs initiates intracellular processing of junctional constituents. In cell B, Der p 1 is envisaged to operate indirectly on TJs by first activating a cell surface zymogen, which then proceeds to cleave the TJs. Intracellular processing arises from TJ perturbation as in $\mathrm{A}$, or through a signal transduction pathway that ultimately affects TJs. Note that in $\mathrm{A}$, we do not exclude the operation of a similar decoupled signal transduction pathway from contributing to the intracellular proteolysis. In both A and B, the result is the opening of the epithelial barrier and delivery of allergen $(C)$. therefore unlikely to have been directly degraded by Der $\mathrm{p} 1$, we propose that its breakdown is a consequence of TJ disassembly. A similar explanation has been invoked to explain intracellular cleavage of the transmembrane protein $\mathrm{N}$-cadherin following loss of intercellular contacts (48).

The possible modes of action of Der $\mathrm{p} 1$ on TJs are shown schematically in Figure 11. To summarize, our data are consistent with direct extracellular cleavage of occludin, and possibly claudins (mechanism in cell A). This may trigger intracellular processing, or, alternatively, intracellular cleavage could arise through a receptor and transduction pathway that is decoupled from TJs (the cell surface receptor and intracellular pathway in cell B). However, it seems less likely that TJs are degraded by activation of a cell surface zymogen that then attacks TJs (extracellular pathway in cell B). Whatever the mechanism of intracellular proteolysis, the effect is to open the epithelial barrier (cell C).

TJ cleavage evoked by HDMFP or Der $\mathrm{p} 1$ differs from other exogenous proteinases that cause aberrant TJ-like strands to be formed (49-52). However, aberrant $\mathrm{TJ}$ strands increase the plasticity of TJs because paracellular permeability increases during their formation (50). This difference in behavior between Der p 1 and certain other proteinases might explain why Der $\mathrm{p} 1$ is an insidious allergen capable of promoting a high level of reactivity in individuals with a constitutional predisposition to allergy.

Our results indicate that epithelial permeability is changed nonselectively by HDMFPs and pure Der $\mathrm{p} 1$. This disruption was demonstrated using mannitol, which permeates the epithelial barrier only paracellularly (53), providing a sensitive index of TJ function (29). Furthermore, and of significance for allergen presentation, the increased permeability following TJ cleavage facilitated the transepithelial permeation of Der $\mathrm{p}$ 1.The nonselectivity of the increase implies that the transepithelial permeation of all proteins would be enhanced. This would lead to an increased probability of any inhaled allergen being able to encounter antigen-presenting cells of the airway's immune system at sites where epithelial permeability was increased. We note that allergy to Der $\mathrm{p} 1$ is frequently associated with reactivity to unrelated allergens (54-56), as would be anticipated from our proposed mechanism.

Our observations suggest that allergic sensitization may be promoted by any environmental proteinase that attacks, directly or indirectly, the integrity of the epithelial barrier. We therefore suggest that prevention of TJ disruption (by inhibiting the environmental proteinase or even promoting TJ reassembly/assembly) could provide an entirely new approach to the treatment of asthma by limiting exposure of the immune system to allergens.

\section{Acknowledgments}

We are grateful to the National Asthma Campaign for financial support. We thank Bruce Stevenson, Tom Fleming, Shoichiro Tsukita, and the Commonwealth Serum Laboratory for reagents.

\footnotetext{
1. Tovey, E.R., Chapman, M.D., and Platts-Mills, T.A.E. 1981. Mite faeces are a major source of house dust allergens. Nature. 289:592-593.

2. Sporik, R., Holgate, S.T., Platts-Mills, T.A., and Cogswell, J.J. 1990. Exposure to house dust mite allergen (Der p 1) and the development of asthma in childhood. A prospective study. N. Engl. J. Med. 323:502-507.

3. Platts-Mills, T.A., Thomas, W.R., Aalberse, R.C., Vervolet, D., and Chapman, M.D. 1992. Dust mite allergens and asthma: report of a second international workshop. J. Allergy Clin. Immunol. 89:1046-1060.

4. Peat, J.K., et al. 1996. House dust mite allergens. A major risk factor for childhood asthma in Australia. Am. J. Respir. Crit. Care Med. 153:141-146.

5. Dowse, G.K., Turner, K.J., Stewart, G.A., Alpers, M.P., and Woolcock, A.J. 1985. The association between Dermatophagoides mites and the increasing prevalence of asthma in village communities within the Papua New Guinea highlands. J. Allergy Clin. Immunol. 75:75-83.

6. Robinson, C., et al. 1997. On the potential significance of the enzymatic activity of mite allergens to immunogenicity. Clues to structure and function revealed by molecular characterization. Clin. Exp. Allergy. 27:10-21.

7. Platts-Mills, T.A., and Carter, M.C. 1997. Asthma and indoor exposure to allergens. N. Engl. J. Med. 336:1382-1384.

8. Holt, P.G. 1997. Dendritic cell populations in the lung and airway wall.
} 
In Asthma. P.J. Barnes, M.M. Grunstein, A.R. Leff, and A.J. Woolcock, editors. Lippincott-Raven Publishers. Philadelphia, PA. 453-463.

9. Anderson, J.M., and Van Itallie, C.M. 1995. Tight junctions and the molecular basis for regulation of paracellular permeability. Am. J. Pbysiol. 269:G467-G475.

10. Schneeberger, E.E., and Lynch, R.D. 1992. Structure, function and regulation of cellular tight junctions. Am. J. Physiol. 262:L647-L661.

11. Farquhar, M., and Palade, G.E. 1963. Junctional complexes in various epithelia. J. Cell Biol. 17:375-412.

12. Haskins, J., Gu, L., Wittchen, E.S., Hibbard, J., and Stevenson, B.R. 1998 $\mathrm{ZO}-3$, a novel member of the MAGUK protein family found at the tight junction, interacts with ZO-1 and occludin. J. Cell Biol. 141:199-208.

13. Denker, B.M., and Nigam, S.K. 1998. Molecular structure and assembly of the tight junction. Am. J. Physiol. 274:F1-F9.

14. Furuse, M., et al. 1993. Occludin: a novel integral membrane protein localising at tight junctions. J. Cell Biol. 123:1777-1788.

15. Ando-Akatsuka, Y., et al. 1996. Interspecies diversity of the occludin sequence: cDNA cloning of human, mouse, dog, and rat-kangaroo homologues. J. Cell Biol. 133:43-47.

16. Furuse, M., et al. 1994. Direct association between occludin and ZO-1 and its possible involvement in the localization of occludin at tight junctions. J. Cell Biol. 127:1617-1626.

17. McCarthy, K.M., et al. 1996. Occludin is a functional component of the tight junction. J. Cell Sci. 109:2287-2298.

18. Furuse, M., Fujita, K., Hiragi, T., Fujimoto, K., and Tsukita, S. 1998. Claudin-1 and -2: novel integral membrane proteins localizing at tight junctions with no sequence similarity to occludin. J. Cell Biol. 141:1539-1550.

19. Van Itallie, C.M., and Anderson, J.M. 1997. Occludin confers adhesiveness when expressed in fibroblasts. J. Cell Sci. 110:1113-1121.

20. Furuse, M., Sasaki, H., Fujimoto, K., and Tsukita, S. 1998. A single gene product, claudin-1 or -2 , reconstitutes tight junction strands and recruits occludin in fibroblasts. J. Cell Biol. 143:391-401.

21. Stewart, G.A., Thompson, P.J., and Simpson, R.J. 1989. Protease antigens from house dust mite [published erratum appears in Lancet, 2:462, 1989]. Lancet. 2:154-155.

22. Anderson, J.M., Stevenson, B.R., Jesaitis, L.A., Goodenough, D.A., and Mooseker, M.S. 1988. Characterization of ZO-1, a protein component of the tight junction from mouse liver and Madin-Darby canine kidney cells. J. Cell Biol. 106:1141-1149.

23. Cozens, A.L., et al. 1994. CFTR expression and chloride secretion in polarized immortal human bronchial epithelial cells. Am. J. Respir. Cell Mol. Biol. 10:38-47.

24. Winton, H.L., et al. 1998. Class specific inhibition of house dust mite proteinases which cleave cell adhesion, induce cell death and which increase the permeability of lung epithelium. Br. J. Pharmacol. 124:1048-1059.

25. Yeates, D.B., Besseris, G.J., and Wong, L.B. 1997. Physicochemical properties of mucus and its propulsion. In The lung: scientific foundations. $2 \mathrm{nd}$ edition. R.G. Crystal, J.B. West, E.R. Weibel, and P.J. Barnes, editors. Lippincott-Raven Publishers. Philadelphia, PA. 487-503.

26. Weibel, E.R. 1991. Design of airways and blood vessels considered as branching trees. In The lung: scientific foundations. R.G. Crystal, J.B. West, editors. Raven Press. New York, NY. 711-720

27. Stewart, G.A., Bird, C.H., Krska, K.D., Colloff, M.J., and Thompson, P.J. 1992. A comparative study of allergenic and potentially allergenic enzymes from Dermatophagoides pteronyssinus, D. farinae and Euroglyphus maynei. Exp. Appl. Acarol. 16:165-180.

28. Stewart, G.A., Lake, F.R., and Thompson, P.J. 1991. Faecally derived hydrolytic enzymes from Dermatophagoides pteronyssinus: physicochemical characterisation of potential allergens. Int. Arch. Allergy Appl. Immunol. 95:248-256.

29. Winton, H.L., et al. 1998. Cell lines of pulmonary and non-pulmonary origin as tools to study the effects of house dust mite proteinases on the regulation of epithelial permeability. Clin. Exp. Allergy. 28:1273-1285.

30. Luczynska, C.M., et al. 1989. A two-site monoclonal antibody ELISA for the quantification of the major Dermatophagoides spp. allergens, Der p 1 and Der f 1. J. Immunol. Methods. 118:227-235.

31. Sakakibara, A., Furuse, M., Saitou, M., Ando-Akatsuka, Y., and Tsukita, S. 1997. Possible involvement of phosphorylation of occludin in tight junction formation. J. Cell Biol. 137:1393-1401.

32. Parrish, E.P., Steart, P.V., Garrod, D.R., and Weller, R.O. 1987. Antidesmosomal monoclonal antibody in the diagnosis of intracranial tumours. J. Pathol. 153:265-273.

33. Soeller, C., and Cannell, M.B. 1996. Construction of a two-photon microscope and optimisation of illumination pulse duration. Pflügers Arch. 432:555-561.

34. Barrett, A.J., et al. 1982. L-trans-epoxysuccinyl-leucylamido(4-guanidino)butane (E-64) and its analogues as inhibitors of cysteine proteinases including cathepsins B, H and L. Biochem. J. 201:189-198.

35. Johnstone, A., and Thorpe, R. 1987. Immunochemistry in practice. Blackwell Scientific Publications. Oxford, United Kingdom. 180-182.

36. Chua, K.Y., et al. 1988. Sequence analysis of cDNA coding for a major house dust mite allergen, Der p I. Homology with cysteine proteases. J. Exp. Med. 167:175-182.

37. Herbert, C.A., et al. 1995. Augmentation of permeability in the bronchial epithelium by the house dust mite allergen Der p 1. Am. J. Respir. Cell Mol. Biol. 12:369-378.

38. Topham, C.M., Srinivasan, N., Thorpe, C.J., Overington, J.P., and Kalsheker, N.A. 1994. Comparative modelling of major house dust mite allergen Der p I: structure validation using an extended environmental amino acid propensity table. Protein Eng. 7:869-894.

39. Schulz, O., Laing, P., Sewell, H., and Shakib, F. 1995. Der p I, a major allergen of the house dust mite, proteolytically cleaves the low-affinity receptor for human IgE (CD23). Eur. J. Immunol. 25:3191-3194.

40. Hewitt, C.R.A., Brown, A.P., Hart, B.J., and Pritchard, D.I. 1995. A major house dust mite allergen disrupts the immunoglobulin $\mathrm{E}$ network by selectively cleaving CD23: innate protection by antiproteases. J. Exp. Med. 182:1537-1544

41. Schulz, O., Sewell, H., and Shakib, F. 1998. Proteolytic cleavage of CD25, the $\alpha$ subunit of the human $\mathrm{T}$ cell interleukin 2 receptor, by Der $\mathrm{p} 1$, a major mite allergen with cysteine protease activity. J. Exp. Med. 187:271-275.

42. Kalsheker, N.A., et al. 1996. The house dust mite allergen Der p 1 catalytically inactivates $\alpha_{1}$-antitrypsin by specific reactive centre loop cleavage: a mechanism that promotes airway inflammation and asthma. Biochem. Biophys. Res. Commun. 221:59-61.

43. Wong, V. 1997. Phosphorylation of occludin correlates with occludin localization and function at the tight junction. Am. J. Physiol. 273:C1859-C1867.

44. Hirokawa, T., Boon-Chieng, S., and Mitaku, S. 1998. SOSUI: classification and secondary structure prediction system for membrane proteins. Bioinformatics. 14:378-379.

45. Wong, V., and Gumbiner, B.M. 1997. A synthetic peptide corresponding to the extracellular domain of occludin perturbs the tight junction permeability barrier. J. Cell Biol. 136:399-409.

46. Alecio, M.R., Dann, M.L., and Lowe, G. 1974. The specificity of the $S_{1}{ }^{\prime}$ subsite of papain. Biochem. J. 141:495-501.

47. Morita, S., Furuse, M., Fujimoto, K., and Tsukita, S. 1999. Claudin multigene family encoding four-transmembrane domain protein components of tight junction strands. Proc. Natl. Acad. Sci. USA. 96:511-516.

48. Volk, T., Volberg, T., Sabanay, I., and Geiger, B. 1990. Cleavage of A-CAM by endogenous proteinases in cultured lens cells and in developing chick embryos. Dev. Biol. 139:314-326.

49. Meyer, H.W., Freytag, C., Freytag, T., and Richter, W. 1988. Effect of proteases and other treatments on the proliferative assembly of tight junction strands in the rat prostate tissue. Exp. Pathol. 34:237-244.

50. Lynch, R.D., et al. 1995. Basolateral but not apical application of protease results in a rapid rise of transepithelial electrical resistance and formation of aberrant tight junction strands in MDCK cells. Eur. J. Cell Biol. 66:257-267.

51. Cohen, E., Talmon, A., Faff, O., Bacher, A., and Ben-Shaul, Y. 1985. Formation of tight junctions in epithelial cells. I. Induction by proteases in a human colon carcinoma cell line. Exp. Cell Res. 156:103-116.

52. Faff, O., Cohen, E., Bacher, A., and Ben-Shaul, Y. 1987. Proteinaseinduced formation of focal tight junctions in HT 29 adenocarcinoma cells does not require extracellular calcium. Biochim. Biophys. Acta. 905:48-56.

53. Dawson, D.C. 1977. Na and Cl transport across the isolated turtle colon: parallel pathways for transmural ion movement. J. Membr. Biol. 37:213-233.

54. Pollart, S.M., Chapman, M.D., Fiocco, G.P., Rose, G., and Platts-Mills, T.A.E. 1989. Epidemiology of acute asthma: IgE antibodies to common inhalant allergens as a risk factor for emergency room visits. J. Allergy Clin. Immunol. 83:875-882.

55. Gelber, L.E., et al. 1993. Sensitization and exposure to indoor allergens as risk factors for asthma among patients presenting to hospital. Am. Rev. Respir. Dis. 147:573-578.

56. Sears, M.R., et al. 1989. The relative risk of sensitivity to grass pollen, house dust mite and cat dander in the development of childhood asthma. Clin. Exp. Allergy. 19:419-424. 